\title{
Strategi Peningkatan Kinerja Sektor Pariwisata Indonesia Pada Asean Economic Community
}

\author{
Victoria Lelu Sabon ${ }^{1 *}$, Mochamad Tommy Putra Perdana ${ }^{2}$, Permata Citra Stella Koropit ${ }^{3}$, \\ Wajong Christian David Pierre ${ }^{4}$ \\ Surya University \\ 1victoria.sabon@surya.ac.id, 2tommywungkulpb@gmail.com, 3citrakoropit@gmail.com, \\ ${ }^{4}$ cwajong@gmail.com \\ ${ }^{*}$ Penulis korespondensi
}

\begin{abstract}
Tourism industry has the important role in attracting manpower. In Indonesia, the tourism sector is one of the 11 jobs that absorb the most labor. By 2015 the tourism industry contributes 10\% from Indonesia GDP total with the highest nominal in ASEAN. On the beginning of 2016 officially started the ASEAN Economic Community (AEC), that is a cooperation to improve the economic, political, and cultural performance of 10 ASEAN countries. It is necessary to improve the performance of Indonesia tourism in order to compete in AEC. Those are the background of doing this research. The method of this research is using qualitative research methodology with techniques of data collection by literature study and interviews, that were conducted with two interviewees from the Indonesia Ministry of Tourism. Output result of this research is recommendations for improving the performance of Indonesian tourism sector. Keywords: Indonesia tourism, ASEAN economic community, government policy, tourism infrastructure funding.

Abstrak

Sektor pariwisata memiliki peranan penting dalam menarik banyak tenaga kerja. Di Indonesia, sektor pariwisata termasuk salah satu dari 11 pekerjaan yang paling banyak menyerap tenaga kerja. Pada tahun 2015 sektor pariwisata menyumbang 10\% dari total GDP Indonesia dengan jumlah nominal tertinggi di ASEAN. Pada awal tahun 2016 resmi dimulai ASEAN Economic Community (AEC) yang merupakan kerja sama untuk peningkatan kinerja ekonomi, politik, dan budaya 10 negara ASEAN. Perlu dilakukan peningkatan kinerja sektor pariwisata Indonesia agar dapat bersaing di AEC. Hal tersebut merupakan latar belakang dari penelitian ini. Metode penelitian dilakukan dengan menggunakan pendekatan kualitatif, dengan teknik pengumpulan data melalui studi literatur, dan wawancara kepada dua narasumber dari Kementerian Pariwisata RI. Luaran dari penelitian ini berupa rekomendasi untuk meningkatkan kinerja sektor pariwisata Indonesia.
\end{abstract}

Kata kunci: pariwisata Indonesia, masyarakat ekonomi ASEAN, kebijakan pemerintah, pendanaan infrastruktur pariwisata.

\section{Cara Mengutip:}

Sabon, V. L., Perdana, M. T. P., Koropit. P, C, S., \& Pierre, W. C. D. (2018). Strategi Peningkatan Kinerja Sektor Parawisata Indonesia Pada Asean Economic Community. Esensi: Jurnal Bisnis dan Manajemen. Vo.8 (2): 163 - 176. doi: 10.15408/ess.v8i2.5928. 


\section{PENDAHULUAN}

Sektor pariwisata merupakan salah satu sektor terbesar dan terkuat dalam perekonomian dunia. Sektor pariwisata menjadi salah satu pendorong utama perekenomian dunia karena terdapat beberapa keuntungan yang mampu memberikan devisa cukup besar bagi negara, memperluas lapangan pekerjaan dan memperkenalkan budaya negara. Menurut United Nations World Tourism Organization (UNWTO), sektor pariwisata berperan penting dalam menyumbang 9\% dari total GDP dunia. Sektor pariwisata mampu menarik banyak tenaga kerja, hal ini menjadikan sektor pariwisata sebagai satu dari 11 pekerjaan yang paling banyak menyerap tenaga kerja. Pada tahun 2014 sektor pariwisata telah menyumbang 6\% dari total ekspor dunia atau sebesar US\$ 1.5 triliun (UNWTO, 2014).

Kawasan ASEAN (Association of Southeast Asian Nations) sering disebut sebagai "surga wisata" di Asia karena memiliki kekayaan yang melimpah dalam hal pariwisata. Negara dengan tujuan utama pariwisata di ASEAN diantaranya Indonesia, Thailand, Malaysia, Singapura, dan Filipina. Untuk mendorong pertumbuhan sektor pariwisata di negara-negara ASEAN, salah satu upaya yang dilakukan adalah dengan diselenggarakannya ASEAN Tourism Forum (ATF) yang bertujuan untuk membuat ASEAN sebagai tujuan utama wisatawan (Effendi, 2010).

Pada tahun 2016 tercatat total kunjungan wisatawan mancanegara ke Indonesia adalah 11,519,275 wisman (BPS, 2017). Salah satu destinasi utama dari wisatawan mancanegara ke Indonesia adalah Pulau Bali. Bali menjadi tujuan utama wisatawan karena daya tarik keindahan alam dan budayanya, selain itu tujuan lain turis datang ke Bali adalah untuk MICE (Meeting, Incentive, Conference, Exhibition) serta bisnis.

Dalam melakukan kunjungan, wisman memerlukan berbagai macam sarana dan prasarana yang mendukung. Hal ini menjadi salah satu faktor yang mempengaruhi tingkat kunjungan wisman (Sri, 2013). Sebuah Organisasi Internasional bernama World Economic Forum (WEF) mengeluarkan indikator-indikator penilaian kinerja sektor pariwisata setiap negara atau disebut Travel \& Tourism Competitiveness Index (TTIC). Indeks TTIC mengukur bagaimana kebijakan yang diterapkan suatu negara dalam mendukung pembangunan dan keberlanjutan travel \& tourism (T\&T), yang akan memberikan daya tarik dan daya saing pariwisata diantara negara-negara dunia. Berdasarkan indeks TTIC Indonesia menempati peringkat ke-50 dunia dan peringkat ke-4 ASEAN setelah Singapura, Malaysia, dan Thailand (World Economic Forum, 2015). Beberapa hal yang masih perlu dibenahi agar kinerja sektor pariwisata dapat meningkat diantaranya: sarana dan prasarana, pengelolaan sektor pariwisata seperti sumber daya manusia, serta kebijakannya

Pada awal tahun 2016 telah resmi dimulai ASEAN Economic Community (AEC)/ masyarakat ekonomi ASEAN. AEC bertujuan untuk menjaga stabilitas politik dan keamanan regional ASEAN, meningkatkan daya saing kawasan secara keseluruhan di pasar dunia, mendorong pertumbuhan ekonomi, mengurangi kemiskinan, serta meningkatkan standar hidup masyarakat. Dengan diberlakukannya $A E C$, maka batasan-batasan antar negara di wilayah Asia Tenggara semakin membaur dimana tenaga kerja, barang dan jasa serta investasi dapat keluar masuk diantara negara-negara ASEAN. Oleh karena, itu Indonesia perlu mempersiapkan diri agar siap bersaing. 
Sektor pariwisata Indonesia dinilai paling siap untuk menghadapi $A E C$ karena Indonesia memiliki potensi pariwisata yang menarik, namun masih memiliki kekurangan seperti infrastruktur yang belum memadai (jalan raya menuju ke lokasi wisata atau lainya). Selain itu, pembangunan dermaga untuk berlabuhnya kapal pesiar juga belum memadai. Dari sisi sumber daya manusia, Indonesia perlu memiliki keterampilan dan kemampuan bersaing, seperti peningkatan produktifitas serta kemampuan berbahasa inggris. Hal lain yang tidak kalah pentingnya adalah pendanaan untuk sektor pariwisata yang berkelanjutan. Hal-hal tersebut merupakan gap/kesenjangan pada sektor pariwisata Indonesia. Oleh karena itu, penelitian ini dilakukan untuk mengkaji sektor pariwisata Indonesia saat ini serta mencari solusi untuk mengurangi gap yang ada.

Tujuan dari penelitian ini adalah mempelajari dan menganalisa faktor-faktor yang mempengaruhi kinerja sektor pariwisata Indonesia dalam menghadapi AEC, yaitu strategi pemasaran, strategi pendanaan, strategi pembangunan infrastruktur, serta kebijakan sektor pariwisata. Kontribusi dari penelitian ini yaitu faktor-faktor strategi pemasaran, strategi pendanaan, strategi pembangunan infrastruktur, serta kebijakan sektor pariwisata berpengaruh terhadap peningkatan jumlah wisatawan mancanegara (wisman) selama tahun 2010-2016, serta rekomendasi untuk meningkatkan kinerja sektor pariwisata Indonesia pada ASEAN Economic Community (AEC).

Hasil penelitian ini dapat digunakan bagi stakeholders sebagai acuan atau pedoman dalam memberikan gambaran terkait dengan kondisi pariwisata di Indonesia yang memiliki potensi besar untuk semakin ditingkatkan sehingga memberikan hasil yang maksimal. Kontribusi penelitian ini dapat berguna untuk mengkolaborasikan berbagai faktor yang diteliti dibandingkan dengan hanya fokus pada satu faktor saja. Dengan adanya koordinasi yang tepat dari stakeholders maka dapat menciptakan pariwisata Indonesia yag lebih maju baik secara kuantitatif dalam jumlah kunjungan wisman maupun secara kualitatif seperti persepsi pengalaman dan perasaan turis yang menyenangkan saat berkunjung ke Indonesia.

\section{METODE}

Pendekatan penelitian yang digunakan dalam penelitian ini adalah pendekatan penelitian kualitatif. Penelitian kualitatif adalah penelitian yang bersifat deskriptif dan menggunakan analisis. Berdasarkan pendekatan penelitian kualitatif maka peneliti menggunakan teknik pengumpulan data dengan cara studi pustaka dan wawancara. Teknik studi pustaka dilakukan dengan cara mengumpulkan data dari jurnal penelitian ilmiah, laporan statistik, publikasi kementerian/organisasi Internasional dan berita. Sedangkan teknik wawancara dilakukan dengan dua orang narasumber dari Kementerian Pariwisata RI. Narasumber pertama adalah Deputi Bidang Pengembangan Destinasi dan Industri Pariwisata Bapak Dadang Rizky Ratman dan narasumber kedua adalah Asisten Deputi Strategi Pemasaran Pariwisita Mancanegara Ibu Ratna Suranti.

Teknik analisis yang digunakan dalam penelitian ini adalah analisis deskriptif dari faktor-faktor yang diteliti, yaitu menganalisa faktor-faktor yang mempengaruhi kinerja sektor pariwisata Indonesia dalam menghadapi AEC. Faktor yang digunakan dalam penelitian ini bersumber dari Rencana Pembangunan Pariwisata 2015-2019 Indonesia oleh Kementerian 
Perencanaan Pembangunan Nasional, yaitu strategi pemasaran, pendanaan, pembangunan infrastruktur, serta kebijakan (BAPPENAS, 2014). Faktor-fakor dalam Penelitian ini tidak menjalankan model analisis faktor eksploratori maupun konfirmatori, karena faktor-faktor yang digunakan telah ditemukan sebelumnya, kemudian menganalisis faktor tersebut menggunakan situasi dan kondisi di Indonesia.

\section{HASIL DAN PEMBAHASAN}

Berdasarkan data BPS 2017 yang terdapat pada Gambar 1, jumlah wisatawan mancanegara ke Indonesia tahun 2010-2016 terus mengalami peningkatan. Dari data tersebut memperlihatkan bahwa Indonesia memiliki beragam potensi untuk dikembangkan guna meningkatkan kinerja sektor pariwisata.

Gambar 1. Jumlah Wisman Indonesia tahun 2010 - 2016

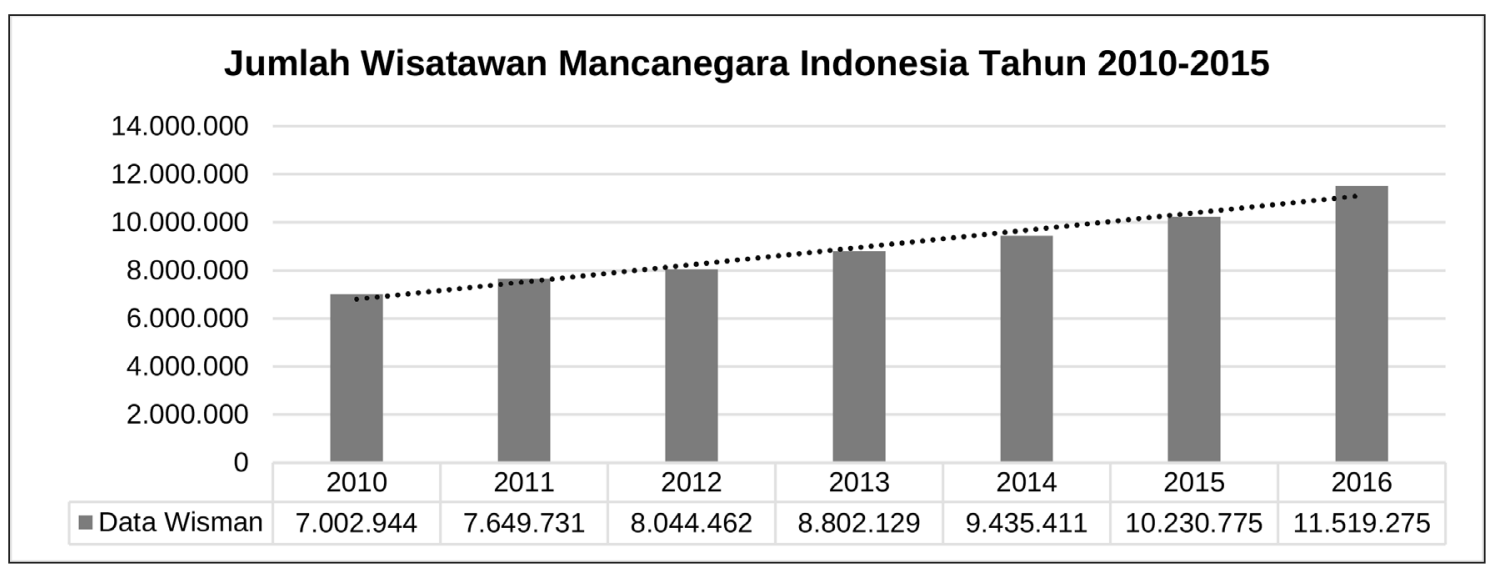

Sumber: BPS, 2017

Berdasarkan data Travel \& Tourism Competitivness Index (TTCI). Indonesia memiliki indikator paling rendah pada infrastructure dan natural and cultural resource. Aksesibilitas menjadi hal yang sangat penting dalam menjamin kenyamanan turis. Kurangnya aksesbilitas pariwisata dikarenakan banyak daerah yang belum menjadikan pariwisata sebagai leading sector serta kurangnya akses informasi. Cara meningkatkan aksesbilitas dapat dilakukan dengan pembangunan infrastruktur, seperti perbaikan jalan, ketersediaan transportasi dan rambu-rambu jalan, peningkatan sarana dan prasarana, serta peningkatan akses informasi melalui media internet seperti media sosial dan website resmi destinasi, dan loket informasi. Pembangunan infrastruktur tersebut dapat menstimulasi terjadinya peningkatan kinerja sektor pariwisata Indonesia sehingga dapat bersaing dengan negara ASEAN lainnya, seperti Singapura dan Thailand.

Indikator lemah lain yang dimiliki oleh Indonesia adalah sumber daya alam dan budaya (natural and cultural resource). Indonesia adalah negara yang kaya akan sumber daya alam dan keanekaragaman budaya. Faktor tersebut yang menarik turis untuk berkunjung. Namun, Indonesia masih belum dapat menjaga keberlanjutan alam. Hal ini terlihat dari terjadinya kerusakan alam yang besar di Indonesia, seperti kebakaran hutan, hampir punahnya berbagai jenis satwa yang dilindungi (seperti orang utan) untuk tujuan bisnis tidak sehat 
di Indonesia. Selain itu, Indonesia masih lemah dalam melestarikan natural. Banyak budaya yang telah hilang dan tidak digunakan lagi, atau budaya Indonesia yang kemudian diakui oleh negara lain.

Untuk itu Indonesia perlu mengelola dan melestarikan budaya dan alamnya. Cara yang tepat agar Indonesia dapat meningkatkan indeks natural and cultural resource adalah dengan membuat event besar tentang kebudayaan Indonesia yang dapat menarik para wisman, misalnya melalui festival kebudayaan. Cara lain adalah dengan membangkitkan kebanggaan masyarakat terhadap budaya, dan menjaga peninggalan bersejarah, benda-benda kuno, bangunan sejarah. Disamping itu, melestarikan seni tradisional seperti musik, drama, tarian, pakaian, dan upacara adat. Kearifan lokal dan budaya dapat menjadi salah satu daya tarik bagi wisatawan untuk berkunjung. Hal ini termasuk keunikan dan kompetensi khas yang dapat ditawarkan oleh sektor pariwisata di Indonesia (Widagdyo, 2017).

Selain budaya, hal lain yang perlu diperhatikan adalah menjaga keberlanjutan alam. Cara-cara yang dapat dilakukan untuk melestarikan alam adalah dengan mendukung program konservasi satwa langka dan lingkungan, memberikan edukasi kepada masyarakat tentang pentingnya kelestarian alam, serta menumbuhkan kesadaran dan pola pikir bahwa alam bukanlah milik pribadi yang dapat dieksploitasi. Dengan adanya keberlanjutan dari alam tersebut maka sektor pariwisata Indonesia akan semakin dihargai dan berkembang sehingga dapat bersaing dengan negara-negara ASEAN pada $A E C$.

Pemasaran pariwisata sangat penting untuk memberikan daya tarik kepada turis asing untuk berkunjung. Data pada Tabel 1 menunjukkan bahwa jumlah anggaran yang dikeluarkan oleh empat negara pariwisata terbesar di ASEAN.

Berdasarkan Data Pada Tabel 1, terlihat bahwa Malaysia mengeluarkan anggaran promosi terbesar. Inbound merupakan jumlah wisman yang berkunjung. Dari data tersebut dapat disimpulkan bahwa pemasaran memiliki peranan penting dalam menarik wisatawan. Indonesia mengeluarkan anggaran promosi lebih rendah dari tiga negara lainnya. Hal ini berdampak pada jumlah wisman yang berkunjung ke Indonesia tidak sebesar ketiga negara tersebut.

Tabel 1. Perbandingan Anggaran Pariwisata Negara Terbesar di ASEAN

\begin{tabular}{cccccc}
\hline No & Comparative Factors & Indonesia & Singapore & Malaysia & Thailand \\
\hline 1 & Inbound & US\$ 8.8 Million & US\$15.6 Million & US\$25.72 Million & US\$26.7 Million \\
2 & Promotion Budget & US\$ 49.6 Million & US\$ 278 Million & US\$300 Million & US\$213 Million \\
3 & Promotion Budget/Inbound & US\$ 5.7 million & US\$ 17.9 million & US\$ 11.6 million & US\$ 8.0 million \\
\hline
\end{tabular}

Sumber: Kementerian Pariwisata RI, 2016

Terdapat tiga strategi pemasaran yang digunakan guna meningkatkan kunjungan Pariwisata di Indonesia, yaitu DOT, BAS, POSE. Strategi customer portofolio yang diterapkan oleh Indonesia adalah pendekatan DOT yang merupakan singkatan dari Destination, Origin, Timeline. Pelaksanaan pendekatan DOT dilakukan berbeda tergantung pada pasarnya. Tiga pasar utama pariwisata Indonesia adalah Asia Tenggara (ASEAN), China, dan Australia. 
Data menunjukkan bahwa wisman yang berasal dari China memiliki tiga destinasi utama, yaitu Bali, Jakarta, dan Kepulauan Riau. Timeline atau waktu kunjungan wisatawan adalah dengan kalender event yang diadakan di Indonesia serta aktivitas pemasaran di China. Selain itu, pendekatan DOT ini memuat aktivitas utama yang dilakukan wisman China, yaitu berbelanja, aktivitas pantai, dan budaya. Informasi wisata juga dimuat dalam pendekatan DOT China, yaitu melalui internet, rekomendasi teman, dan televisi. Hal lain yang termasuk didalamnya adalah jumlah target wisman dan kalender event besar yang bisa mengundang wisman untuk berkunjung ke Indonesia.

Strategi kedua yang digunakan dalam memasarkan pariwisata Indonesia adalah BAS. BAS merupakan singkatan dari Branding, Advertising, Selling. Branding dari Pariwisata Indonesia adalah Wonderful Indonesia dengan gambar burung yang terdiri atas 5 warna, pada Gambar 2.

Gambar 2. Lambang Wonderful Indonesia

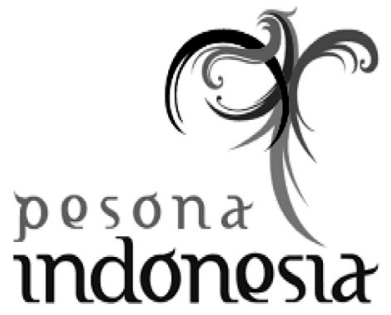

\begin{tabular}{cc}
\hline WARNA & MAKNA \\
\hline Biru & Kesemestaan \\
Hijau & Kreatifitas dan Ramah pada Alam \\
Jingga & Inovasi dan Pembaharuan \\
Ungu & Imajinasi dan Keimanan \\
Magenta & Keseimbangan akal sehan dan praktis \\
\hline & Sumber. www.kemenpar.go.id
\end{tabular}

Setelah branding dibuat maka aktivitas selanjutnya adalah advertising. Advertising dilakukan melalui tv komersial, event marketing, kerja sama dengan website luar negeri seperti website travel Amerika Serikat TripAdvisor, iklan di media cetak dan online, maupun billboard. Cara terbaru yang dilakukan adalah iklan yang ditayangkan di bioskop sebelum pemutaran film. Iklan Pariwisata Indonesia ini ditayangkan di 55 bioskop di 14 kota di Indonesia. Terdapat tiga program, yaitu cara kita, Wonderful Indonesia, dan keindahan alam 15 destinasi utama di Indonesia. Selain itu, pemerintah bekerja sama dengan maskapai penerbangan Garuda Indonesia serta beberapa maskapai internasional seperti Singapura untuk pemasangan brand pariwisata Wonderful Indonesia.

Setelah brand dan advertising maka tahap selanjutnya adalah selling. Selling adalah tahapan dimana penjualan wisata Indonesia sendiri seperti wisata alam, kerajinan tangan ataupun oleh-oleh, kenikmatan pariwisata, maupun dalam sektor MICE. Contoh kegiatan yang diadakan untuk mendukung selling adalah "Bali Beyond Travel Fair" yang diadakan setiap tahun di Bali. 
Strategi ketiga yang digunakan dalam pemasaran pariwisata Indonesia adalah kerja sama dengan media. Strategi tersebut adalah POSE (Paid Media, Own Media, Social Media, Endorser). Paid Media adalah pemasaran yang dilakukan dengan media yang dibayar, seperti Discovery Channel, CNN, Metro TV, Youtube, National Geographic Channel, dan CCTV. Terdapat beberapa negara yang menutup akses terhadap media luar negeri, contohnya China, yang melarang masyarakatnya menggunakan google sebagai mesin pencarian. Oleh karena itu, pemerintah Indonesia bekerja sama dengan salah satu media di China, yaitu Baidu Browser yang merupakan browser resmi dan mesin pencarian di China.

Setalah paid media, pemasaran dilakukan dengan own media, yaitu dengan menggunakan media resmi untuk pemasaran, seperti website resmi Kementrian Pariwisata Indonesia atau website resmi Wonderful Indonesia. Media lain yang digunakan adalah melalui social media. Social media digunakan dengan membagikan tautan atau informasi tentang pariwisata di Indonesia, dengan adanya media sosial ini maka masyarakat juga dapat ikut terlibat dalam memasarkan pariwisata di Indonesia. Strategi terakhir adalah Endorser. Endorser dilakukan melalui kontrak dengan beberapa Artis untuk menjadi ambassador pariwisata Indonesia, seperti Raisa, Pevita Pearce serta yang terbaru adalah Prof. Philip Kotler. Pendanaan bagi sektor pariwisata dapat dilakukan melalui investasi. Investasi di Indonesia terdiri atas Penanaman Modal Dalam Negeri (PMDN) dan Penanaman Modal Asing (PMA).

Gambar 3 memperlihatkan jumlah Realisasi Investasi di Indonesia tahun 2011-2015 melalui Penanaman Modal Asing (PMA) dan Penanaman Modal Dalam Negeri (PMDN). Berdasarkan hasil tersebut dapat disimpulkan bahwa setiap tahunnya terjadi peningkatan realisasi investasi di Indonesia, dengan demikian prospek pendanaan untuk sektor pariwisata juga dapat ditingkatkan. Menurut BKPM, total realisasi investasi yang menunjang akomodasi pariwisata seperti restoran dan hotel pada tahun 2015 adalah sebesar Rp. 4.62 triliun atau 0.8 persen dari realisasi investasi tahun 2015. Hampir 50 persen dari total realisasinya berfokus di Pulau Jawa. Indonesia masih memiliki banyak daerah yang perlu dikembangkan seperti pulau Sulawesi, Kalimantan, Maluku, dll. Pendanaan yang dilakukan dimulai dari aksesbilitas, infrastruktur, akomodasi, dan situs pariwisata. Jika realisasi investasi terdistribusi secara merata dan terus ditingkatkan, maka pendanaan bagi pariwisata Indonesia juga akan meningkat.

Gambar 3. Jumlah Realisasi Investasi di Indonesia tahun 2011 - 2015

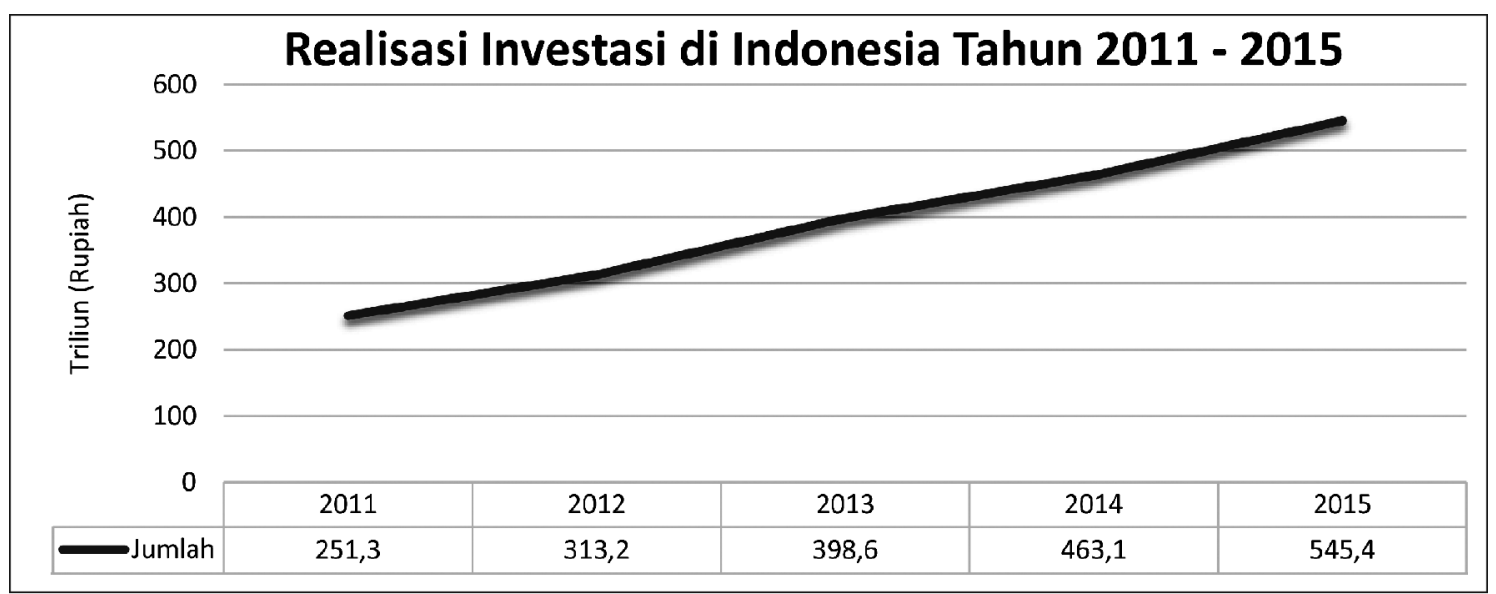

Sumber. Badan Koordinasi Penanaman Modal (BKPM) Republik Indonesia, 2016 
Salah satu proyek besar yang sedang dikerjakan oleh pemerintah dan membutuhkan dana adalah 10 destinasi utama. Proyek tersebut memerlukan dana USD 20 miliar. Salah satu tujuan utamanya adalah menarik investor China. Kemudian dari hasil investasi yang didapatkan, 50 persen akan digunakan untuk meningkatkan infrastruktur seperti jalan tol, bandara, dll; dan 50 persen berikutnya akan digunakan untuk membangun akomodasi seperti hotel, restoran, dan fasilitas lainnya.

Selain dari investasi, pendanaan pariwisata juga berasal dari pemerintah pusat maupun daerah. Menurut UU RI Nomor 10 Tahun 2009 Tentang Kepariwisataan pada Bab XIII Tentang Pendanaan disebutkan bahwa Pendanaan pariwisata menjadi tanggung jawab Bersama, Pemerintah Pusat, Pemerintah Daerah, pengusaha, dan masyarakat. Pendanaan yang dilakukan oleh pemerintah menggunakan APBN dan APBD. Pada tahun 2015 Anggaran yang dikeluarkan untuk sektor pariwisata dan ekonomi kreatif sebesar Rp. 2.4 Triliun atau 0.1 persen dari belanja pemerintah pusat (BPP). Jumlah ini meningkat dari tahun 2014 sebesar 11.7 persen. Dana APBN tersebut digunakan untuk program pengembangan destinasi pariwisata, program pengembangan pemasaran pariwisata, program pengembangan sumber daya pariwisata dan ekonomi kreatif, program pengembangan ekonomi kreatif berbasis seni dan budaya, dan program pengembangan ekonomi kreatif berbasis media, desain, dan IPTEK.

Pada tahun 2016 pemerintah menargetkan BPP untuk pariwisata sebanyak 1\% dari total APBN atau setara dengan Rp.5,4 Triliun. Hal ini dilakukan untuk mewujudkan pariwisata yang lebih maju dan mampu bersaing dalam AEC. Dengan dana yang semakin meningkat pemerintah menargetkan wisatawan asing tahun 2016 dapat mencapai 12 juta wisman atau setara dengan 260 juta perjalanan di tahun 2016, namun realisasinya sedikit dibawah target tersebut yaitu 11.519.275 wisman yang datang berkunjung di tahun 2016 .

Infrastuktur dalam pariwisata merupakan salah satu unsur penunjang yang sangat penting, karena jika tidak ada infrastruktur yang memadai maka akses untuk ketempat destinasi pariwisata akan sulit sehingga wisatawan jarang berkunjung. Dari destinasi yang ditargetkan harus disertai peningkatan infrastruktur, seperti pembangunan sarana dan prasarana transportasi, pembangunan fasilitas umum, pemeliharaan kawasan, penyediaan BBM dan listrik, penyiapan daya tarik wisata, dan kelembagaan pengembangan destinasi.

Strategi pemerintah untuk pembangunan infrastruktur destinasi pariwisata akan difokuskan pada 10 destinasi pariwisata untuk meningkatkan kunjungan wisatawan. 10 Destinasi Prioritas Pariwisata Indonesia adalah Borobudur, Bromo, Danau Toba, Kepulauan Seribu, Labuan Bajo, Mandalika, Morotai, Tanjung Kelayang, Tanjung Lesung, dan Wakatobi.

Pengembangan dan peningkatan pariwisata dalam suatu negara sangatlah penting, karena dengan destinasi pariwisata yang terawat dan tertata baik akan semakin mendatangkan wisatawan baik nusantara maupun mancanegara. Untuk mewujudkan hal tersebut, maka diperlukannya regulasi yang dapat mengatur dan mengontrol peningkatan kinerja pariwisata. Regulasi atau kebijakan yang dikeluarkan oleh pemerintah untuk meningkatkan wisatawan, diantaranya:

Kebijakan Pembebasan Visa terdapat pada Peraturan Presiden Republik Indonesia Nomor 104 Tahun 2015 Tentang Perubahan Atas Peraturan Presiden Nomor 69 Tahun 2015 Tentang Bebas Visa Kunjungan. Kebijakan ini bertujuan untuk meningkatkan hubungan 
Indonesia dengan negara lain dan memberikan kemudahan bagi warga negara asing untuk berkunjung ke Indonesia. Sebelumnya Kebijakan Bebas Visa tersebut berlaku untuk 45 negara berdasarkan Peraturan Presiden Nomor 69 Tahun 2015.

Saat ini pemerintah Indonesia telah menambah daftar negara bebas visa ke Indonesia menjadi 169 negara, sesuai Peraturan Presiden Nomor 21 Tahun 2016 yang ditandatangani Presiden Joko Widodo pada tanggal 2 Maret 2016. Kebijakan tersebut bertujuan untuk meningkatkan pertumbuhan wisman yang datang ke Indonesia dengan harapan kunjungan meningkat $19 \%$ atau sebesar 20 juta wisman. Target tersebut dinilai tertinggi, karena sebelumnya hanya menargetkan $6-8 \%$ dari total pertumbuhan wisatawan mancanegara.

Data pada Tabel 2 memperlihatkan jumlah wisman yang berkunjung ke ASEAN baik intra ASEAN maupun extra ASEAN dimana pada tahun 2015 terbanyak ke Thailand dan Malaysia, sedangkan Indonesia berada di peringkat ke-3. Hal ini terjadi karena Malaysia telah menetapkan kebijakan bebas visa kepada 160 negara sejak tahun 2014 sehingga menarik wisman untuk berkunjung.

Tabel 2. Jumlah Wisatawan yang berkunjung ke ASEAN

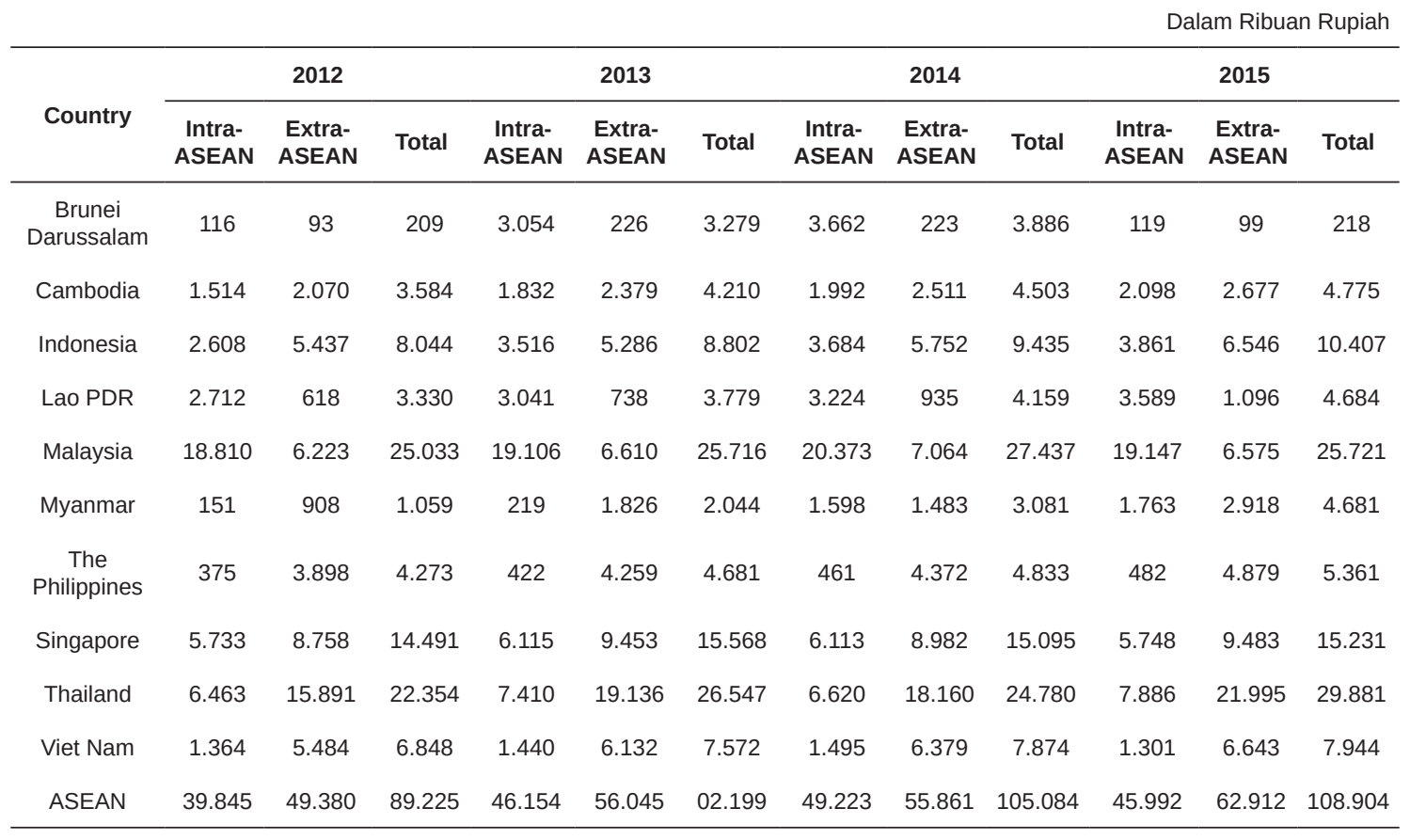

Sumber: ASEAN Stastistic Database, 2017

Kebijakan pengembangan destinasi prioritas untuk meningkatkan kunjungan wisman. Terdapat sepuluh destinasi prioritas yang terbagi menjadi dua jenis yaitu, kawasan strategis pariwisata nasional dan kawasan ekonomi khusus pariwisata. Kawasan ekonomi khusus ada tiga, yaitu Tanjung Lesung, Gunung Bromo, Pulau Morotai. Sedangkan Kawasan strategis pariwisata nasional melingkupi Danau Toba, Kepulauan Seribu, Tanjung Lesung, Tanjung Kelayang, Borobudur, Madalika, Wakatobi, dan Labuan Bajo.

Gambar 4 merupakan perencanaan untuk semua kementerian dalam mengembangkan 10 destinasi utama pariwisata. Pengembangan destinasi tersebut memiliki kriteria, yaitu 
Nilai daya tarik (atraksi) yang berkualitas, Kesiapan amenitas pariwisata (Infrastruktur dan sarana prasarana pariwisata), Aksesbilitas (Jaringan moda transportasi dan konektivitas), Kesiapan dan dukungan masyarakat dan pemerintah daerah, Tata kelola destinasi pariwisata, dan Potensi pengembangan pasar mancanegara dan nusantara. Oleh karena itu pemerintah melakukan perencanaan terintegritas dengan berbagai kementerian. Pengembangan destinasi ini bertujuan tidak hanya untuk meningkatkan wisman tetapi juga untuk meningkatkan devisa secara signifikan.

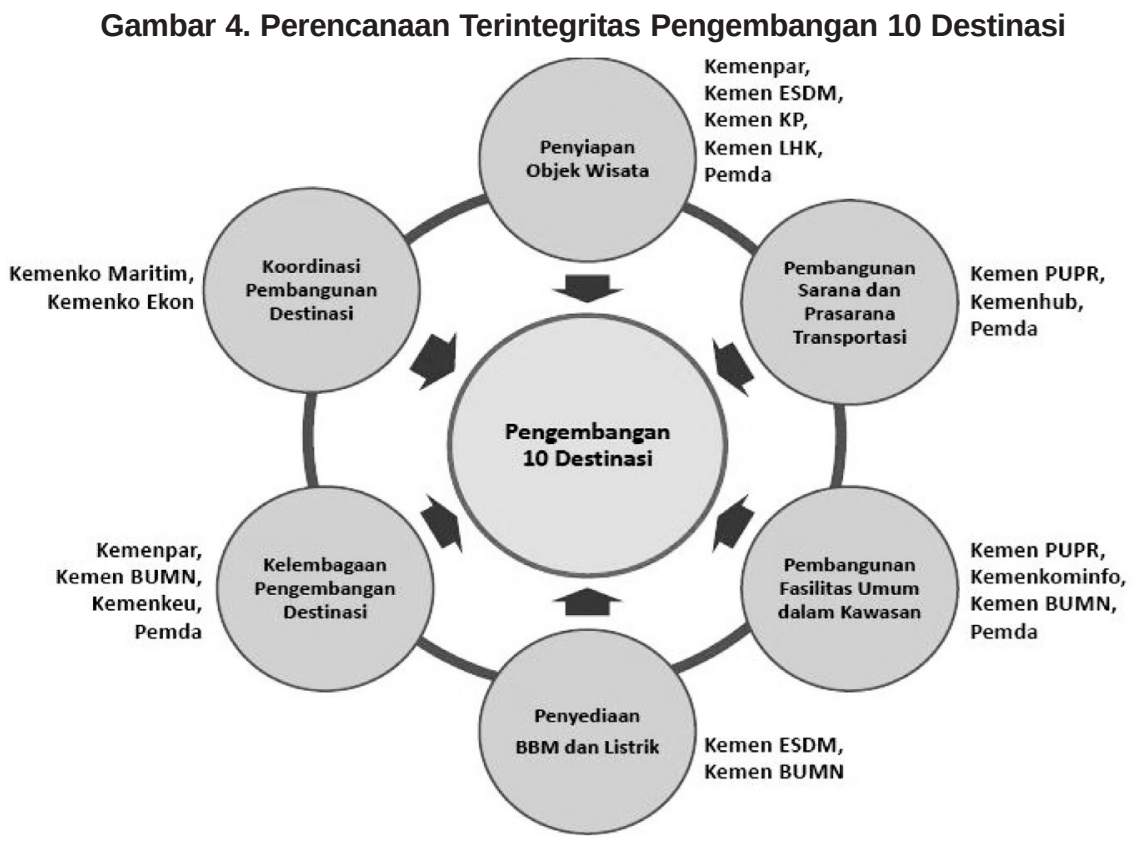

Sumber: Kementerian Pariwisata RI, 2016

Berdasarkan data dari Kementerian Pariwisata RI, kualitas sumber daya manusia pada tahun 2009 hingga tahun 2013 Indonesia berada di peringkat 4 ASEAN, sedangkan secara global pada tahun 2013 Indonesia berada di peringkat 61 dari 140 negara. Oleh karena itu, pemerintah membuat kebijakan yaitu pelatihan berbasis kompetensi. Pelatihan ini bertujuan untuk meningkatkan kompetensi dalam aspek sikap, pengetahuan dan keterampilan.

Tabel 3 merupakan Job Titles yang disepakati dalam Mutual Recognition Agreement (MRA) pada Masyarakat Ekonomi Asean. Sektor Pariwisata Indonesia telah memiliki 30 SKKNI pada 11 bidang pekerjaan (job titles) yang telah menjadi peraturan menteri tenaga kerja. Sektor pariwisata telah mempunyai 16 LSP (Lembaga Sertifikasi Profesi), serta 121.627 tenaga kerja bersertifikasi sudah tersebar di berbagai provinsi. Pelatihan berbasis kompetensi merupakan salah satu perwujudan dari pasal 52 UU No 10 Tahun 2009 tentang Kepariwisataan yaitu pemerintah pusat dan pemerintah daerah menyelanggarakan pelatihan SDM pariwisata. Salah satu contoh standar kompetensi yang telah setara dengan negara-negara lain adalah standar cleaning service di hotel A pasti sama dengan hotel B di negara lain. 
Tabel 3. Job Titles yang disepakati dalam Mutual Recognition Agreement (MRA) dalam Masyarakat Ekonomi Asean

\begin{tabular}{|c|c|c|c|c|c|}
\hline No & Jenis Pekerjaan & No & Jenis Pekerjaan & No & Jenis Pekerjaan \\
\hline \multicolumn{2}{|c|}{ Front Office } & \multicolumn{2}{|c|}{ Food Poduct } & 23 & Public Area Cleaner \\
\hline 1 & FO Manager & 12 & Demmi Chef & \multicolumn{2}{|c|}{ Travel Agencies } \\
\hline 2 & FO Supervisor & 13 & Commis Chef & 24 & General Manager \\
\hline 3 & Receptionist & 14 & Chef de Partie & 25 & Assistant General Manager \\
\hline 4 & Telepone Operator & 15 & Commis Pastry & 26 & Senior Travel Consultant \\
\hline 5 & Bell Boy & 16 & Baker & 27 & Travel Consultant \\
\hline \multicolumn{2}{|c|}{ Food and Beverage } & 17 & Butcher & \multicolumn{2}{|c|}{ Tour Operator } \\
\hline 6 & F \& B Director & \multicolumn{2}{|c|}{ House Keeping } & 28 & Product Manager \\
\hline 7 & F \& B Outlet Manager & 18 & Executive HouseKeeper & 29 & Sales \& Marketing Manager \\
\hline 8 & Head Waiter & 19 & Laundry Manager & 30 & Credit Manager \\
\hline 9 & Bartender & 20 & Floor Supervisor & 31 & Ticketing Manager \\
\hline 10 & Waiter & 21 & Laundry Attendant & 32 & Tour Manager \\
\hline 11 & Waiter Executive Chef & 22 & Room Attendant & & \\
\hline
\end{tabular}

Sumber: Kementerian Pariwisata RI, 2016

Selain itu, kelembagaan tenaga kerja Indonesia telah bekerja sama dengan lembaga regional dan internasional (ASEAN, APEC, PATA, UNWTO, WTTC, ILO, dan sebagainya). Pengembangan kelembagaan pemerintah dan swasta, termasuk didalamnya peningkatan kualitas sumber daya manusia, aparatur, masyarakat, dan swasta, peningkatan kualitas dan diseminasi penelitian kebijakan kepariwisataan. Penerapan pelatihan SDM dan kerja sama kelembagaan yang dilakukan pemerintah saat ini sangat menunjang pariwisata Indonesia di $A E C$.

Pembangunan infrastruktur dapat menstimulasi terjadinya peningkatan kinerja sektor pariwisata Indonesia sehingga dapat bersaing dengan negara ASEAN lainnya, seperti Singapura dan Thailand. Pembangunan infrastruktur yang dilakukan seperti perbaikan jalan, ketersediaan transportasi dan rambu-rambu jalan, peningkatan sarana dan prasarana, serta peningkatan akses informasi melalui media internet seperti media sosial dan website resmi destinasi, dan loket informasi. Hal serupa juga dikemukakan Masyono dan Suhada (2015) dan Amalia (2016), bahwa banyak hal yang harus dipersiapkan untuk menunjang peningkatan kinerja sektor pariwisata. Itamar, dkk (2014) menyakan bahwa akses infrastruktur yang terbatas dapat menjadi faktor penghambat pengembangan sektor pariwisata.

Mulyana (2012) dalam penelitiannya juga menerangkan bahwa sebagian besar wisatawan mendapatkan informasi tentang objek wisata melalui media elektronik dan internet, selain melalui rekomendasi dari teman/keluarga/agen travel. Ketersebaran informasi akan mampu meningkatkan minat berkunjung dari para wisatawan baik domestik maupu mancanegara.

Indonesia perlu mengelola dan melestarikan budaya dan alamnya. Sri (2013) menyatakan bahwa motivasi wisatawan untuk mengunjungi objek wisata karena memiliki panorama alam yang indah, adat-istiadat, dan budaya yang unik beserta kesenian, sejarah, 
makanannya, keramahtamahan masyarakatnya. Widagdyo (2017) menyatakan pula bahwa faktor petualang dan budaya mampu memengaruhi minat wisatawan untuk berkunjung.

Branding dari Pariwisata Indonesia adalah Wonderful Indonesia telah meningkatnya kunjungan wisatawan mancanegara ke Indonesia sejak tahun 2011. Idriasih (2016) juga menyimpulkan bahwa Kampanye Wonderful Indonesia telah menunjukkan prestasi yang mengagumkan.

MICE merupakan salah satu tahapan pada Selling yang sangat berperan untuk promosi wisata Indonesia. Deni dan Sopian (2017) juga menyatakan bahwa MICE menjadi alat promosi secara tidak langsung untuk memperkenalkan destinasi wisata yang ada di negara yang menjadi tempat pertemuan kegiatan tersebut.

Sektor pariwisata berpengaruh terhadap peningkatan ekonomi suatu negara. Wijaya (2013) juga menemukan bahwa sektor pariwisata, di kelompok negara yang PMA tinggi (Indonesia, Malaysia, Singapura, Vietnam), maupun yang PMA rendah (Brunei Darussalam, Kamboja, Laos, Filipina, Thailand), sama - sama memiliki dampak positif dan signifikan terhadap produk domestik bruto (PDB). Dengan bertambahnya wisatawan asing ke Indonesia akan turut menambah pemasukan devisa negara, hal serupa juga dikemukakan oleh Hakim (2010).

Regulasi diperlukan untuk dapat mengatur dan mengontrol peningkatan kinerja pariwisata. Hashrawi dan Sugihartoyo (2015), dan Moenir (2017) juga menerangkan bahwa kebijakan pariwisata perlu diimplementasikan guna percepatan pertumbuhan ekonomi dan perbaikan pariwisata Indonesia. Hal serupa dinyatakan pula oleh Rani (2014) dan Setiabudi (2016), dimana objek wisata mampu memberikan sumbangsih bagi peningkatan pendapatan asli daerah.

Berdasarkan data Jumlah Wisatawan Mancanegara (wisman) Indonesia tahun 2010 - 2016 pada Gambar 1 menunjukkan angka jumlah wisman yang selalu meningkat setiap tahunnya mulai dari tahun 2010 sebesar 7 juta wisman hingga tahun 2016 sebesar 11 juta lebih wisman, meningkat sebesar 65\%. Hal tersebut menunjukkan bahwa faktor Strategi Pemasaran, Strategi Pendanaan, Strategi Pembangunan Infrastruktur, serta Kebijakan sektor Pariwisata yang telah dijalankan telah mempengaruhi jumlah wisman secara positif.

Pemerintah penting pula kiranya melibatkan peran aktif masyarakat dalam mengembangan sektor pariwisata. Hal ini akan berdampak signifikan pada perekonomian masyarakat setempat (Resnawaty, 2016). Hal ini dapat terlihat pada Kabupaten Banyuwangi yang mengembangkan pariwisata berbasis masyarakat. Peningaktan kualitas sumber daya manusia menjadi hal yang tak kalah pentingnya dalam pengembangan sektor pariwisata (Aripradana dan Widayaningsih, 2006).

Jika faktor-faktor tersebut terus ditingkatkan maka akan meningkatkan kinerja sektor pariwisata Indonesia pada ASEAN Economic Community (AEC). Pada akhirnya branding Wonderful Indonesia semakin populer di kawasan ASEAN dan kancah Internasional, sehingga jumlah wisatawan ke Indonesia kian meningkat. Selain itu, Utami (2016) menyatakan bahwa sektor pariwisata harus memiliki kompetensi khas yang dapat menjadi keunikan tersendiri bagi wisatawan. Setiap objek wisata harus mampu menampilkan keunikan tersendiri yang dapat dijual untuk menarik minat berkunjung wisatawan. 


\section{SIMPULAN}

Simpulan dari penelitian sebagai berikut: Pertama, faktor Strategi Pemasaran, Strategi Pendanaan, Strategi Pembangunan Infrastruktur, serta Kebijakan sektor Pariwisata yang telah diterapkan telah mempengaruhi jumlah wisman secara positif. Kedua, pembebasan Visa terhadap 169 negara di dunia, termasuk seluruh anggota ASEAN untuk berkunjung ke Indonesia untuk mencapai target peningkatan wisatawan ke Indonesia. Hasil positif dari adanya pembebasan visa, jumlah kunjungan wisatawan dari tahun 2011 hingga tahun 2016 meningkat sebesar 65\% atau sekitar 10\% pertahun. Ketiga, kebijakan pengembangan 10 destinasi prioritas, telah memberikan hasil positif pada pengembangan leading sector pariwisata di 10 destinasi pariwisata yaitu Tanjung Lesung, Gunung Bromo, Pulau Morotai, Danau Toba, Kepulauan Seribu, Tanjung Lesung, Tanjung Kelayang, Borobudur, Mandalika, Wakatobi, dan Labuan Bajo. Keempat, jika faktor-faktor yang mempengaruhi jumlah wisman terus ditingkatkan maka akan meningkatkan kinerja sektor pariwisata Indonesia pada masyarakat ekonomi ASEAN (ASEAN Economic Community).

Rekomendasi untuk peningkatan kinerja sektor pariwisata Indonesia pada AEC, sebagai berikut: Pertama, Berdasarkan indikator Travel and Tourism Competitiveness Index (TTCI) pada indikator infrastruktur, memperbaiki dan meningkatkan infrastruktur seperti pembangunan jalan, dana sarana prasarana yang mendukung aksesibilitas wisatawan. Selain itu, dalam indikator natural and cultural resource pemerintah perlu mendorong masyarakat untuk lebih peduli terhadap lingkungan dan kebudayaan agar tercipta keberlanjutan lingkungan dan budaya. Kedua, bagi Pengusaha yang bergerak di bidang pariwisata didorong untuk semakin aktif melakukan kegiatan promosi pariwisata melalui media sosial (twitter, path, instagram, dll.) dimana tidak memerlukan biaya besar. Ketiga, bagi Peneliti selanjutnya untuk melakukan penelitian lebih dalam tentang faktor atau potensi lainnya yang dimiliki pariwisata Indonesia untuk meningkatkan kinerja pariwisata Indonesia. Keempat, bagi Masyarakat dapat terlibat dalam pendanaan pariwista, dengan cara membeli saham BUMN yang berhubungan langsung dengan pariwisata, sehingga menambah investasi bagi pariwisata Indonesia.

\section{DAFTAR PUSTAKA}

Amalia, L. D. A. P. (2016). Efektivitas ASEAN Tourism Strategic Plan 2011-2015 di Indonesia. Jurnal Analisis Hubungan Internasional, Vol. 5 (1): 258-267.

Aripradana., \& Widayaningsih, N. (2006). Strategi Pengembangan Sektor Pariwisata Kabupaten Banyumas. Eko-Regional. Vol. 1 (2): 73-84.

Badan Pusat Statistik (BPS). (2017). Jumlah Kedatangan Wisatawan Mancanegara ke Indonesia menurut Pintu Masuk, 1997-2016. Jakarta: Badan Pusat Statistik.

Badan Perencanaan Pembangunan Nasional (BAPPENAS). (2014). Pembangunan Pariwisata 2015-2019. Jakarta: Bappenas.

Badan Perencanaan Pembangunan Nasional (BAPPENAS). (2016a). Multilateral Meeting II 18 April 2016 Kedeputian Bidang Ekonomi. Jakarta: BAPPENAS.

Badan Perencanaan Pembangunan Nasional (BAPPENAS). (2016b). Pembangunan Pariwisata. Jakarta: Bappenas. 
Deni, F., \& Sopian, P. (2017). Peran Asean Tourism Forum Dalam Meningkatkan Pariwisata Indonesia Periode 2011-2015. Journal International \& Diplomacy. Vol. 2 (2): 279-307.

Hakim, L. (2010). Industri Pariwisata dan Pembangunan Nasional. Among Makarti. Vol. 3 (5): 70-78.

Hashrawi, G. A., \& Sugihartoyo. (2015). Strategi Pengembangan Pariwisata di Pulau Belakang Padang. Jurnal Planesa. Vol. 6 (2): 51-59.

Idriasih, G. (2016). Diplomasi Indonesia melalui Kampanye Wonderful Indonesia dalam Meningkatkan Pariwisata Indonesia di Dunia Internasional Tahun 2011-2015. JOM FISIP. Vol. 3(1): 1-15.

Itamar, H., Alam, A. S., \& Rahmatullah. Strategi Pengembangan Pariwisata di Kabupaten Tana Toraja. Government: Jurnal Ilmu Pemerintahan. Vol. 7 (2): 91-108.

Masyono, S. A., \& Suhada, B. (2015). Strategi Pengembang Sektor Kepariwisataan di Kabupaten Lampung Timur. Derivatif. Vol. 9 (1): 129-139.

Moenir, H. D. (2017). Implementasi ASEAN Tourism Strategic Plan 2011-2015 dalam Kebijakan Pariwisata Indonesia di masa Pemerintahan Jokowi. Andalas Journal of International Studies. Vol. 6 (1): 57-78.

Mulyana, B. (2012). Pengembangan Kota Bogor Sebagai Destinasi Pariwisata Internasional. Jurnal Ilmiah Pariwisata. Vol. 2 (1): 109-222.

Rani, D. P. M. (2014). Pengembangan Potensi Pariwisata Kabupaten Sumenep, Madura, Jawa Timur (Studi Kasus: Pantai Lombang). Jurnal Politik Muda. Vol. 3 (3): 412-421.

Resnawaty, R. (2016). Strategi Community Practice dalam Pengembangan Pariwisata Berbasis Masyarakat. Share: Social Work Journal. Vol. 6 (1): 105-118.

Rizky, D. (2016). Pembangunan Destinasi Pariwisata Prioritas 2016 - 2019. Rapat Koordinasi Nasional Kementerian Pariwisata. Jakarta: Kemenpar.

Setiabudi, A. (2016). Pembangunan Sektor Pariwisata Dalam Meningkatkan Pendapatan Asli Daerah (Studi Pada Dinas Kebudayaan dan Pariwisata Kabupaten Lumajang). Jurnal Administrasi Publik. Vol. 4 (3): 221-230.

Sri, A. A. P. (2013). Faktor-Faktor Yang Memotivasi Perempuan Sebagai Pengelola Pondok Wisata Di Kelurahan Ubud, Kabupaten Gianyar. Jurnal Analisis Pariwisata. Vol. 13 (1): 1-10.

Utami, A. R. (2016). Kompetensi Khas di Sektor Pariwisata. Esensi: Jurnal Bisnis dan Manajemen. Vol. 6 (1): 75-88. doi: https://doi.org/10.15408/ess.v6i1.3121.

Widagdyo, K. G. (2017). Pemasaran, Daya Tarik Ekowisata dan Minat Berkunjung Wisatawan. Esensi: Jurnal Bisnis dan Manajemen. Vol. 7 (2): 261-276. doi: https://doi.org/10.15408/ ess.v7i2.5411.

Wijaya, OIB. (2013) Pengaruh Sektor Pariwisata Terhadap PDB Negara - Negara Asean Periode 2000 - 2010. Jurnal Ilmiah Mahasiswa Universitas Surabaya. Vol. 2 (1): 1-14.

World Economic Forum, W. (2015). The Travel \& Tourism. Geneva: World Economic Forum.

World Tourism Organization, U. (2014). Why tourism? Retrieved Januari 27, 2016, from World Tourism Organization UNWTO: http://www2.unwto.org/content/why-tourism. 